\title{
VERSITA
}

Ekológia (Bratislava)

Vol. 32, No. 2, p. 262-266, 2013

doi:10.2478/eko-2013-0022

\section{INVASIVE PLANT SPECIES IN THE THREE MICROREGIONS OF NITRA REGION, SOUTH-WEST SLOVAKIA}

\section{ŽANETA PAUKOVÁ}

Department of Ecology, Faculty of European Studies and Regional Development, Slovak Agricultural University in Nitra, Mariánska 10, 94976 Nitra, Slovak Republic; e-mail: zaneta.paukova@uniag.sk

\begin{abstract}
Pauková Ž.: Invasive plant species in the three microregions of Nitra region, south-west Slovakia. Ekológia (Bratislava), Vol. 32, No. 2, p. 262-266, 2013.

Alien plant species were recorded by field survey in three selected microregions (submontane in district Zlaté Moravce, hilly in district Nitra and lowland in districts Nové Zámky) in Nitra region, SW Slovakia in 2011. In the microregions totally 19 invasive neophytes were recorded. The most frequent and abundant species were the following: Ailanthus altissima, Ambrosia artemisiifolia, Conyza canadensis, Fallopia x bohemica, Helianthus tuberosus, Iva xanthiifolia, Negundo aceroides, Robinia pseudoacacia, Solidago canadensis and Stenactis annua. On the basis of the data we can preliminary conclude that the number of species and the number of localities in the southern lowland microregion were almost twice higher than those in the northern hilly region.
\end{abstract}

Key words: Alien invasive plants, neophytes, Nitra, SW Slovakia.

\section{Introduction}

Biological invasions have been recognized as being one of the main components of global change (Shea, Chesson, 2002) that affects populations, communities and even whole ecosystems (Richardson et al., 2000; Drake et al., 1989). The rapid spread of non-native invasive plant species is causing irreparable and indiscriminate damage across many habitat types. Highly productive invasives compete for resources, change population dynamics, and enhance ecosystem processes (Drake et al., 1989; Mack, D’Antonio, 1998). Mapping invasive plant populations is critical for strategic management and monitoring. It is also essential for effective early detection. Knowing where a plant currently grows is the foundation for knowing where to survey for new occurrences.

We study the occurrence and distribution as well as the recent expansion and the invasive behaviour of non-native species in the selected microregions. The report presents a brief overview of invasive plants in selected areas of Nitra region (SW Slovakia).

\section{Material and methods}

The following three microregions of the Nitra region were chosen for the study of non-native plants distribution:

1. Collective farm at Neverice in northern district Zlaté Moravce (cadastres of five villages Neverice, Ladi- 
ce, Kostolany pod Tribečom, Slažany, Velčice) in foothill territory of Tribeč Mts, Western Carpathians. Microregion has an altitude of 170 to $800 \mathrm{~m}$, the area drained by the river Žitava. Northern part of the cadastre of the mountains lies in Tribeč, on the eastern slopes of the nuclear crystalline mountains. Climatic zone is slightly warm (Abaffy et al., 2002).

2. Velké Zálužie and surroundings in district Nitra (microregion, cadastres of five villages Vel'ké Zálužie, Jarok, Lehota, Báb, Rumanová) in hilly territory of Danube lowland. Micro-region has an altitude of 132 $245 \mathrm{~m}$. It is located in Nitra hills, in the northernmost tip of the Danube lowland. There is warm climatic zone with mild winters. Lowland type of climate - hot subtype lowland climate (Abaffy et al., 2002).

3. Southern microregion Dvory nad Žitavou and surroundings (villages Dvory nad Žitavou, Pribeta, Dubník, Rúbaň, Svätý Peter) in lowland territory. Microregion has an altitude of 122-250 m. They are located in the lowland. There is warm climatic zone mild winters and long sunshine (Abaffy et al., 2002).

Focus of work has its own field survey of the alien plants in all selected villages in the three microregions of the Nitra region, in Summer 2011. Localities of alien plant species were recorded and published data on invasive plants were verified. For identification of the aliens we used the list of invasive plants of Slovakia by Gojdičová et al. (2002). Of these, nine are invasive plants according to law in Slovakia (Ambrosia artemisiifolia, Fallopia $\times$ bohemica, F. japonica, F. sachalinensis, Helianthus tuberosus, Heracleum mantegazzianum, Impatiens glandulifera, Solidago canadensis and S. gigantea) and are necessary to carry out management (Vyhláška, 2011). Nomenclature of species is listed by Marhold, Hindák (1998). The data recorded are presented in Table 1 - presence or absence of a species in a village (cadastre), frequency of the species in the microregions and number of alien species recorded in the microregions.

\section{Results and discussion}

The invasive alien plants recorded in the microregions are listed in Table 1. In field survey we confirmed and newly identified localities of 19 invasive plant species in Summer 2011. We can preliminary conclude that in the northern microregion, in the foothill area of the collective farm Neverice occurs the lowest number of localities with invasive plants. And we have found approximately one-half more localities in the lowland area of Dvory nad Žitavou and surroundings.

The most frequently occurring species were Solidago canadensis and Stenactis annua in the 12 villages. Invasive Solidago canadensis occurred in villages where they were planted as ornamental plants. They escaped from the cultures; they expanded and spread further on abandoned areas in villages and on the banks of rivers outside the urban areas. Stenactis annua occurs in all three microregions, quite often, but singly and scattered and only rarely forms dense vegetation.

In field surveys, we documented that Fallopia $\times$ bohemica is present in all three microregions. We found that F. $\times$ bohemica and F. japonica form there on several places, a dense monospecific stands. We found on the earlier identified localities and they spread in territories outside of urban areas. F. $\times$ bohemica is the most expanding and the most dynamic invading herbaceous plant in the area. Management to limit the local populations/stands in the villages has not been successful, e.g. in village Slažany.

Helianthus tuberosus spreads along rivers, in towns, villages and outside too. It grows in gardens in different places as an ornamental plant. Near the historical park in village Rumanová we found its expansive spread in the garden of a family house in an area approx. 900 $\mathrm{m}^{2}$.

Impatiens parviflora occurred mainly in three villages Kostolany pod Tribečom and Velčice in collective farm Neverice and in village Báb in July 2011. This species is cultivated in gardens too (Eliáš, 1990a, b); it occurred only in peripheral parts of the mountains Tribeč. 


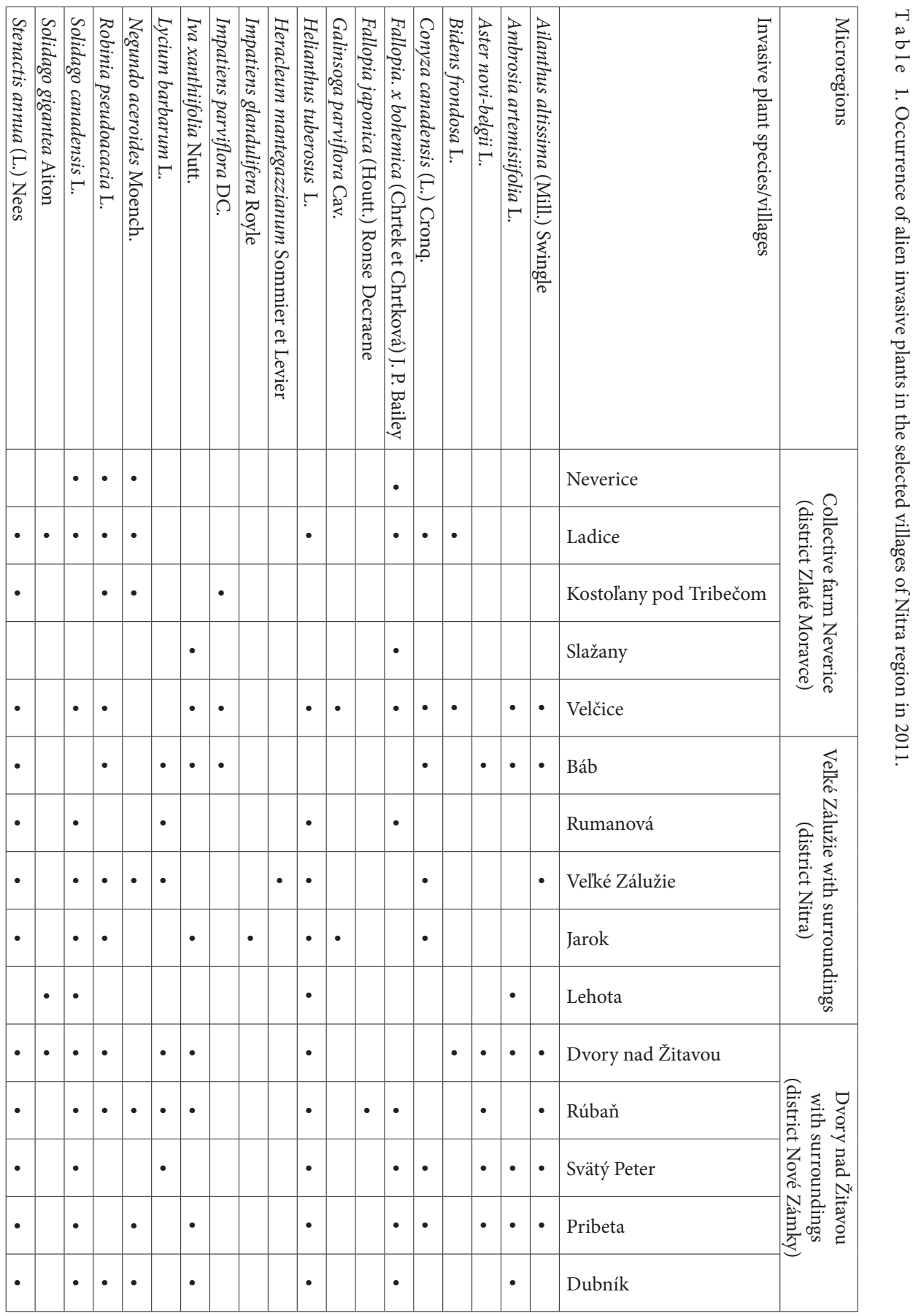


I. parviflora was introduced into the Bábsky forest (Eliáš, 2000, 2001, 2010), where it recently dominates on the clearings and illuminated parts of the forest (Eliáš et al., 1999; Fehér, 2001); it occurs along the watercourses of the river Nitra.

We recorded Ailanthus altissima, Negundo aceroides, Robinia pseudoacacia, Lycium barbarum and others also in Báb forest (Table 1). Ailanthus altissima is spread especially in towns, where it was planted as a plant resistant to air pollution. Mature trees are found on most localities in district Nové Zámky. In Bábsky forest, it occurred in the forest overgrowth and after logging. A. altissima behaves as a dominant woody plant on clearing in the National Nature Reserve Bábsky les. Robinia pseudoacacia are often planted as an ameliorative anti-erosion and melliferous tree species. Little woods with $R$. pseudoacacia are in all microregions. Eliáš (1971) notes that in Velčice they are known as 'Robinia ditches', e.g. more or less deep erosion rills in agricultural landscape with the overgrowth of $R$. pseudoacacia. We recorded that in the villages these trees were planted near the Calvary locality and historical monuments that are old now. R. pseudoacacia has invasive behaviour in and outside urban areas. Its occurrence was observed and mapped in 10 villages.

It was evident for Ambrosia artemisiifolia, which has recently expanded along the roads and created dense vegetation on abandoned (non-cultivated) agricultural fields. We recorded the presence of species in the three studied microregions, namely in villages Dvory nad Žitavou, Svätý Peter, Pribeta and Dubník. We found new localities in Velčice (at forest roads and at bait stations) and in village Lehota (at the highway Nitra-Báb). Jehlík et al. (1998) referred occurrence $A$. artemisiifolia on the bus station 1980, in a tomato field west of the village 1988, in maize Dvory nad Žitavou 1991; in the village Rúbaň 1988, in the village Svätý Peter 1978, 1980, 1982, Dvor Mikuláš (between Dvory nad Žitavou a Pribeta), not customized areas around the village Pribeta 1987.

Species Bidens frondosa, Galinsoga parviflora, Heracleum mantegazzianum, Impatiens glandulifera and Solidago gigantea were occurring rarely (Table 1). Heracleum mantegazzianum was recorded only in village Vel'ké Zálužie. It was first recorded by Svobodová (1999) in village Vel'ké Zálužie 'along the brook below the hill Stračí. Fehér (2000) counted 65 generative plants there. Pauková, Eliáš (2010) registered the occurrence of $H$. mantegazzianum in the collective farm in Velké Zálužie, in direction of the former dump. In the habitat we recorded seven individuals with a height of $1.7 \mathrm{~m}$, three yellow rosettes. On the left side of the field road nine generative individuals were recorded in 2010.

\section{Conclusion}

In three microregions of the Nitra region - (a) collective farm Neverice in the northern district Zlaté Moravce, (b) Vel'ké Zálužie with surroundings in district Nitra, and (c) Dvory nad Žitavou with surroundings in the southern district Nové Zámky - we recorded by field survey the occurrence of 19 invasive plants in Summer 2011. The lowest number of localities with invasive species (31) is in the northern microregion, in foothill villages. Vice versa, the highest number of the alien species is in the southern microregion, lowland villages (up to 50 localities) along the road of expanding into Hungary. In all three microregions, the most frequently observed invading species were Ambrosia artemisiifolia, Fallopia $\times$ bohemica, $\mathrm{He}$ - 
lianthus tuberosus, Iva xanthiifolia, Solidago canadensis, Stenactis annua, of trees Ailanthus altissima and Robinia pseudoacacia.

\section{Acknowledgements}

The research was done with the financial support from the Scientific Grant of Agency of Sciences and Ministry of Education SR VEGA in the research project VEGA no. 1/0869/10 'Environmental determinants of life quality in rural areas'.

I wish to express my thanks to Mrs. Jana Kolenová for language correction of the text.

\section{References}

Abaffy, D. et al. (2002). Landscape atlas of the Slovak Republic (in Slovak). Bratislava: MŽP SR.

Drake, J.A. et al. (Eds.) (1989). Biological invasions: a global perspective. New York: Wiley.

Eliáš, P. (1971). Synanthropic vegetation in Velčice and surrounding areas (in Slovak). Bratislava: Univerzita Komenského.

Eliáš, P. (1990a). Expansion of plants in protected landscape Ponitrie (mountains Tribeč and Vtáčnik). Rosalia, 6, 121-148.

Eliáś, P. (1990b). Invasion of Impatiens parviflora into forest communities. In J. Oszlányi et al. (Eds.), Anthropogenic impacts on stability of forest ecosystems (pp. 57-65). Bratislava: Slovenská akadémia vied.

Eliáš, P., Fehér, A. \& Končeková L. (1999). Expansion and invasive behaviour introduced plant species in the river Nitra. In P. Eliáš (Ed.), Invasion and invasive organisms 2 (pp. 158-164). Bratislava: Slovenská ekologická spoločnost' pri SAV.

Eliáš, P. (2000). Invading alien species in former I.B.P. Forest Research Site at Báb, SW Slovakia (Central Europe). In ESA Abstracts, 85 $5^{\text {th }}$ Annual Meeting/Preannual Meeting ILTER ASM (p. 399). August 6-10. Utah: Snowbird.

Eliáš, P. (2001). Invasion of an oak-hornbeam forest by aliens/exotic plant species: what is the mechanism of plant invasion? (Results of long term studies in Slovakia) In Ecology and management of alien plant invasions (EMA$\mathrm{Pi}$ ), $6^{\text {th }}$ International Conference (conference abstracts) (p. 53). September 12-15, 2001, Loughborough, UK.

Eliáś, P. (2010). Changes in biodiversity in Bábsky forest and surrounding. In Caring of biodiversity in rural land (pp. 150-161). September 23-24, 2010. Nitra: SPU.

Fehér, A. (2000). The current distribution Heracleum mantegazzianum in district Nitra. Rosalia, 6, 79-82.

Fehér, A. (2001). Invasive behaviour plant species in the river Nitra. PhD. Thesis, Slovenská polnohospodárska univerzita, Nitra.

Gojdičová, E., Cvachová, A. \& Karasová E. (2002). List of non-native, invasive and expansive vascular plants of Slovakia 2, vol. 21, (pp. 59-79). Nature protection, Banská Bystrica.

Jehlík, V. et al. (Ed.) (1998). Alien expansive weeds of the Czech Republic and Slovak Republi. Bratislava: VEDA, vydavatel'stvo SAV, Praha: Academia.

Mack, M.C. \& D’Antonio C.M. (1998). Impacts of biological invasions on disturbance regimes. Trends Ecol. Evol., 13, 195-198. DOI: 10.1016/S0169-5347(97)01286-X.

Marhold, K. \& Hindák F. (Eds.) (1998). List of lower and higher plants in Slovakia. Bratislava: VEDA, vydavatel’stvo SAV.

Vyhláška (2011). The list of invasive plant SR. Available at: <http://www.minzp.sk/tlacovy-servis/tlacove-spravy/tlacove-spravy- 2011/tlacove-spravy-jun-2011/novela-vyhlasky-odstranuje-nedostatky-z-minulosti.html>

Pauková, Ž. \& Eliáš P. (2010). Alien invasive, quarantine and problematic plant species in SW Slovakia. In M. Eliašová (Ed.), Caring of biodiversity in rural land (pp. 136-144). September 23-24, 2010. Nitra: Slovenská polnohospodárska univerzita.

Richardson, D.M., Pyšek, P., Rejmánek, M., Barbour, M.G., Panetta, F.D. \& West C.J. (2000). Naturalization and invasion of alien plants: concepts and definitions. Divers. Distrib., 6, 93-107. DOI: 10.1046/j.1472$-4642.2000 .00083 . x . s o n$.

Shea, K. \& Chesson P. (2002). Community ecology theory as a framework for biological invasion. Trends Ecol. Evol., 17, 170-176. DOI:10.1016/S0169-5347(02)02495-3.

Svobodová, Z. (1999). Floristic notes from southern Slovakia (in Slovak). Rosalia, 14, 61-66. 